\title{
IN VITRO ANTIMICROBIAL AND ANTI-INFLAMMATORY ACTIVITY OF METHANOL EXTRACT OF ERANTHEMUM CAPENSE
}

\author{
ANOOPA JOHN L ${ }^{1 *}$, KANNAPPAN N ${ }^{2}$, MANOJKUMAR P ${ }^{1}$ \\ ${ }^{1}$ Department of Pharmaceutical Chemistry, The Dale View College of Pharmacy and Research Centre, Trivandrum, Kerala, India. \\ ${ }^{2}$ Department of Pharmacy, Annamalai University, Annamalai Nagar, Tamil Nadu, India. Email: anoopajohnl@gmail.com
}

Received: 18 October 2019, Revised and Accepted: 06 December 2019

\section{ABSTRACT}

Objective: The present study was aimed to rationalize the scientific basis in traditional use of Eranthemum capense as an antibacterial, antifungal, and anti-inflammatory agent.

Methods: Agar well diffusion method is widely used to evaluate the antimicrobial activity of the E. capense aerial part of methanolic and ethyl acetate plant extracts. The same amount (15-20 mL) of Mueller-Hinton agar was poured on glass Petri plates of same size and allowed to solidify. E. capense aerial part of methanolic and ethyl acetate extracts was evaluated in vitro for their anti-inflammatory activities using the bovine serum albumin protein denaturation assay.

Results: The result of the study shows that methanolic exract (T3) of the plant, E. capense shows 16 mm zone of inhibition against Pseudomonas fluorescens, while the ethyl acetate extract of the same plant shows $14 \mathrm{~mm}$ zone of inhibition against P. fluorescens and E. coli. Hence the methanolic extract of T3 sample shows the antibacterial activity against gram negative bacteria, where as the ethyl acetate extract of T3 shows antibacterial activity against both gram positive and gram negative bacteria. The experimental report revealed that, the methanolic and ethyl acetate extract of the same plant produces zero percentage zone of inhibition against Aspergillus niger and Mucor, hence it does not show any antifungal activity.

Conclusion: It is observed that the EA and methanolic extract of E. capense can be used in the treatment of inflammation due to the significant percentage of inhibition of protein denaturation as well as its prove the good antimicrobial agent.

Keywords: Eranthemum capense, Antibacterial, Antifungal, Anti-inflammatory, Denaturation, Inhibition.

(C) 2020 The Authors. Published by Innovare Academic Sciences Pvt Ltd. This is an open access article under the CC BY license (http://creativecommons. org/licenses/by/4. 0/) DOI: http://dx.doi.org/10.22159/ajpcr.2020.v13i2.36119

\section{INTRODUCTION}

Natures fauna and flora gave us a complete store of remedies to treat the ailments of suffering humankind [1,2]; hence, these natural drugs have been used since ages as cure for diseases as they contain natural chemical compounds of the therapeutic value of Eranthemum capense. Inflammation is generally referred to as a complex biological response of vascular tissues to harmful stimuli [3]. As well, inflammation is associated with pain, and it involves in an increase of protein denaturation, protein denaturation has been identified as the cause of inflammation [4]. Indications are that when living tissues are injured, inflammation results $[5,6]$. This is characterized by redness, pain, heat, swelling, as well as loss of function in the affected area [7,8]. Disruption of the electrostatic, hydrogen, hydrophobic, and disulfide bonds in the protein structure occurs [9]. In addition, a complex array of enzyme activation, mediator release, cell migration, tissue breakdown, and repair occurs, causing the protein to lose its molecular conformation and functions or becomes denatured. Recently, traditional medicine worldwide is being reevaluated by extensive research on different plant species and their active therapeutic principles [10]. Natural products have contributed significantly towards the development of modern medicines. The rich wealth of the plant kingdom can represent a novel source of newer compounds with significant anti inflammatory activities [11].

E. capense (L.) Willd. Family: Acanthaceae. Conventionally, the plant has been used for some medicinal purposes in the Indian subcontinent [12]. The aerial part plant has been used in folk medicine to treat stomach ulcers. The plant is thought to be efficacious in the treatment of gastric problems. Conventionally, its leaf juice is applied to the affected area of the body in the treatment of wounds and bruises [13]. The plant is regarded as a rich source of bioactive compounds, especially flavonoids, tannins, phenolic, terpenoids, and steroids which were prominently revealed during the preliminary phytochemical screening. Phenolics, tannins, and steroids were present in the extract, whereas glycosides were absent in the extracts. Alkaloids, terpenoids, and proteins were absent in the extract [14]. The novelty work is to know in vitro antimicrobial and anti-inflammatory activity of methanol $(\mathrm{MeOH})$ extract of E. capense and optimize the concentration which can be more effective.

\section{METHODS}

\section{Plant material}

The aerial parts of E. capense Linn. were collected from Tirunelveli district, Tami Nadu, India, during the month of March 2016. The plant was identified and authenticated by Mr. Chelladurai, Research Officer - Botany, Central Council for Research in Ayurveda and Siddha, Government of India (Ref No:- DCP/CH/AN02).

\section{Extraction}

The aerial parts of E. capense Linn. were collected, shade dried, powdered mechanically, and sieved through No. 40 mesh sieve [15]. About $100 \mathrm{~g}$ of the powdered aerial part is first extracted with petroleum ether (PEE, $60-80^{\circ} \mathrm{C}$ ) and then consecutively with chloroform (CEE), ethyl acetate (EA), and $\mathrm{MeOH}$. The study continued to the plant $\mathrm{EA}$ and $\mathrm{MeOH}$ extract based on the already reported phytochemical study literature. 
Table 1: Antibacterial activity of Eranthemum capense plant extracts

\begin{tabular}{|c|c|c|c|c|c|c|c|}
\hline \multirow[t]{3}{*}{ Microorganisms } & \multicolumn{7}{|c|}{ Zone of inhibition (mm) } \\
\hline & \multirow{2}{*}{$\begin{array}{l}\text { Positive } \\
\text { control } \\
\text { (gentamicin) }\end{array}$} & \multicolumn{3}{|c|}{ МeOH } & \multicolumn{3}{|l|}{ EA } \\
\hline & & T1 & $\mathrm{T} 2$ & T3 & T1 & $\mathrm{T} 2$ & T3 \\
\hline $\begin{array}{l}\text { Staphylococcus } \\
\text { aureus }\end{array}$ & 28 & - & - & & - & - & \\
\hline Bacillus subtilis & 28 & - & - & & - & 10 & 12 \\
\hline $\begin{array}{l}\text { Pseudomonas } \\
\text { fluorescens }\end{array}$ & 19 & 9 & 14 & 16 & 10 & 12 & 14 \\
\hline Escherichia coli & 27 & 11 & 12 & & - & 12 & 14 \\
\hline
\end{tabular}

Table 2: Antifungal activity of Eranthemum capense plant extracts

\begin{tabular}{|c|c|c|c|c|c|}
\hline \multirow[t]{3}{*}{ Microorganisms } & \multicolumn{5}{|c|}{ Zone of inhibition (mm) } \\
\hline & \multirow{2}{*}{$\begin{array}{l}\text { Positive control } \\
\text { (fluconazole) }\end{array}$} & \multicolumn{2}{|c|}{ МеОН } & \multicolumn{2}{|l|}{ EA } \\
\hline & & T1 & $\mathbf{T} 2$ & T1 & T2 \\
\hline Aspergillus niger & 25 & - & - & - & - \\
\hline Mucor & 35 & - & - & - & - \\
\hline
\end{tabular}

Table 3: $\mathrm{IC}_{50}$ value for standard (diclofenac) in protein denaturation inhibitory assay

\begin{tabular}{llll}
\hline $\begin{array}{l}\text { Standard } \\
\text { (diclofenac sodium) }\end{array}$ & $\begin{array}{l}\text { Concentration } \\
(\boldsymbol{\mu g} / \mathbf{m l})\end{array}$ & $\begin{array}{l}\text { \% of } \\
\text { inhibition }\end{array}$ & IC $_{\mathbf{5 0}}$ \\
\hline Control & - & - & $281.85 \pm 1.26$ \\
$\mathrm{~S}_{1}$ & 100 & $23.28 \pm 1.08$ & \\
$\mathrm{~S}_{2}$ & 200 & $47.46 \pm 1.74$ & \\
$\mathrm{~S}_{3}$ & 300 & $70.63 \pm 1.52$ & \\
$\mathrm{~S}_{4}$ & 400 & $89.52 \pm 0.98$ & \\
\hline \multicolumn{4}{l}{ All values determined were mean \pm standard error of the mean; $\mathrm{n}=3 .{ }^{*} \mathrm{p}<0.05$} \\
when compared with standard
\end{tabular}

Table 4: $\mathrm{IC}_{50}$ value for ethyl acetate and extract of Eranthemum capense in protein denaturation inhibitory assay

\begin{tabular}{lllll}
\hline $\begin{array}{l}\text { Sample } \\
\text { name }\end{array}$ & $\begin{array}{l}\text { Marked } \\
\text { as control }\end{array}$ & $\begin{array}{l}\text { Concentration } \\
(\boldsymbol{\mu g} / \mathbf{m l})\end{array}$ & $\begin{array}{l}\boldsymbol{\%} \text { inhibition } \\
(\boldsymbol{\mu g} / \mathbf{m l})\end{array}$ & $\begin{array}{l}\mathbf{I C}_{50} \\
(\boldsymbol{\mu g} / \mathbf{m l})\end{array}$ \\
\hline $\mathrm{EA}$ & $\mathrm{T} 1$ & 250 & $19.6 \pm 0.68$ & $1394.58 \pm$ \\
$(1 \mathrm{mg} / \mathrm{ml})$ & $\mathrm{T} 2$ & 500 & $29.3 \pm 1.02$ & 1.52 \\
& $\mathrm{~T} 3$ & 750 & $31.7 \pm 1.34$ & \\
& $\mathrm{~T} 4$ & 1000 & $38.6 \pm 0.92$ & \\
$\mathrm{MeOH}$ & $\mathrm{T} 1$ & 250 & $31.2 \pm 1.34$ & $802.63 \pm$ \\
$(1 \mathrm{mg} / \mathrm{ml})$ & $\mathrm{T} 2$ & 500 & $40.4 \pm 0.74$ & 1.28 \\
& T3 & 750 & $57.3 \pm 1.22$ & \\
& T4 & 1000 & $64.1 \pm 1.08$ & \\
\hline
\end{tabular}

All values determined were mean \pm standard error of the mean; $n=3 .{ }^{*} p<0.05$ when compared with standard

\section{Procedure}

Well diffusion assay antibacterial

Agar well diffusion method is widely used to evaluate the antimicrobial activity of the plant extracts. The same amount (15-20 mL) of Mueller-Hinton agar was poured on glass Petri plates of same size and allowed to solidify and followed by standardized inoculum of the test organism [16]. Four wells with a diameter of $8 \mathrm{~mm} \mathrm{(20} \mathrm{mm} \mathrm{apart} \mathrm{from}$ one another) were punched aseptically with a sterile cork borer in each plate. Extract solution $(20$ and $40 \mu \mathrm{L})$ at the desired concentration was added to two of the wells and one well with gentamycin as positive and extract solvent as a negative control. Then, the agar plates were incubated under suitable conditions depending on the test microorganism [17]. After incubation, a clear zone was observed. Inhibition of the bacterial growth was measured in $\mathrm{mm}$.

\section{Well diffusion assay antifungal}

Well diffusion assay antimicrobial susceptibility testing was done using the well diffusion method to detect the presence of antifungal activities of the plant samples [18]. A sterile swab was used to evenly distribute fungal culture over the potato dextrose agar medium. The plates were allowed to dry for $15 \mathrm{~min}$ before use in the test [19]. Wells were then created and a pipette was used to place $20-40 \mu \mathrm{l}$ of the sample into each well. The same extract was used on each plate, with a total of two plates used for each extract [20] including two wells for the positive and negative controls. The plates were incubated at room temperature for 3 days, after which they were examined for inhibition zones. A caliper was used to measure the inhibition zones.

Procedure for inhibition of protein denaturation assay

The reaction mixture $(0.5 \mathrm{ml})$ consisted of $0.45 \mathrm{ml}$ bovine serum albumin (3\% aqueous solution) and $0.05 \mathrm{ml}$ isolated fraction ( $250 \mu \mathrm{g} / \mathrm{ml}$ of final volume); $\mathrm{pH}$ was adjusted to 6.3 using a small amount of $1 \mathrm{~N}$ hydrochloric acid. The samples were incubated at $37^{\circ} \mathrm{C}$ for $20 \mathrm{~min}$ and then heated at $80^{\circ} \mathrm{C}$ for $2 \mathrm{~min}$. After cooling the samples, $2.5 \mathrm{ml}$ phosphate buffer saline ( $\mathrm{pH}$ 6.3) was added to each tube [20]. The absorbance was measured using a spectrophotometer at $416 \mathrm{~nm}$. The percentage inhibition of protein denaturation was calculated as follows:

Percentage inhibition=(Abs control-Abs sample $) \times 100 /$ Abs control

\section{RESULTS AND DISCUSSION}

Antibacterial activity of E. capense plant aerial part of EA and methanolic extracts shows a significant role in the Staphylococcus, Bacillus subtilis, Pseudomonas fluorescens, and Escherichia coli. Table 1 intimates the highest zone of the inhibition of methanolic extract of E. capense aerial part test sample $\mathrm{MeOH}$ (T3) against Pseudomonas fluorescens $16 \mathrm{~mm}$ and ethyl acetate extract test sample (T3) of E. capense aerial part against $P$. fluorescens and $E$. coli zone of inhibition $14 \mathrm{~mm}$; hereby, both extracts have significant antibacterial activity compared with standard drug which is proved. Table 2 intimates the antifungal activity $0 \%$ zone of inhibition of $\mathrm{MeOH}$ and ethyl acetate extract test sample of E. capense aerial part test sample against Aspergillus niger and Mucor. The results of testing the diameter of the inhibition zone growth of microorganisms using $\mathrm{EA}$ and $\mathrm{MeOH}$ extract of E. capense showed that the $\mathrm{MeOH}$ fraction had more significant antibacterial effect than EA.

It was effective in inhibiting heat-induced albumin denaturation at different concentrations, as shown in Table 4. Maximum inhibition of EA extract (38.6\%) was observed at $1000 \mu \mathrm{g} / \mathrm{ml}$ and maximum inhibition of $\mathrm{MeOH}$ extract (64.1\%) was observed at $1000 \mu \mathrm{g} / \mathrm{ml}$ IC $_{50}$ value of ethyl acetate extract was found to be $1394.58 \mu \mathrm{g} / \mathrm{ml}$ and the $\mathrm{IC}_{50}$ value of $\mathrm{MeOH}$ extract was found to be $802.63 \mu \mathrm{g} / \mathrm{ml}$. In Table 3, diclofenac sodium, a standard anti inflammatory drug, showed the inhibitions for different concentrations of $100,200,300$ and $400 \mu \mathrm{g} / \mathrm{ml}$. It showed the maximum inhibition $89.52 \%$ at the concentration of $400 \mu \mathrm{g} / \mathrm{ml}$.

\section{CONCLUSION}

The result of the study shows that the EA and methanolic extract of E. capense can be used in the treatment of inflammation due to the significant percentage of inhibition of protein denaturation as well as its prove the good antimicrobial agent. Further investigations are required to find an active component of the extract and to confirm the mechanism of action.

\section{AUTHORS' CONTRIBUTIONS}

All authors have equally contributed for making this case report to be successful. 


\section{CONFLICTS OF INTEREST}

None.

\section{REFERENCES}

1. Huffman MA. Self-medicative behavior in the African great apes: An evolutionary perspective into the origins of human traditional medicine. BioScience 2001;51:651-61.

2. Beidokhti MN, Prakash HS. Antioxidant and anti-inflammatory potential of selected medicinal plants of Lamiaceae family. Int J Pharm Pharm Sci 2013;5 Suppl 1:100-4.

3. Mathieu P, Lemieux I, Després JP. Obesity, inflammation, and cardiovascular risk. Clin Pharmacol Ther 2010;87:407-16.

4. Ross R. Atherosclerosis an inflammatory disease. N Engl J Med 1999;340:115-26.

5. Medzhitov R. Inflammation 2010: New adventures of an old flame. Cell 2010;140:771-6.

6. Leyendecker G, Wildt L, Mall G. The pathophysiology of endometriosis and adenomyosis: Tissue injury and repair. Arch Gynecol Obstet 2009;280:529-38

7. Ferrero-Miliani L, Nielsen OH, Andersen PS, Girardin SE. Chronic inflammation: Importance of NOD2 and NALP3 in interleukin-1beta generation. Clin Exp Immunol 2007;147:227-35.

8. Baron R. Mechanisms of disease: Neuropathic pain a clinical perspective. Nat Rev Neurol 2006;2:95.

9. DeGrado WF, Wasserman ZR, Lear JD. Protein design, a minimalist approach. Science 1989;243:622-8

10. Chandra S, Chatterjee P, Dey P, Bhattacharya S. Evaluation of in vitro anti-inflammatory activity of coffee against the denaturation of protein. Asian Pac J Trop Biomed 2012;2:S178-80

11. Chatterjee P, Chandra S, Dey P, Bhattacharya S. Evaluation of antiinflammatory effects of green tea and black tea: A comparative in vitro study. J Adv Pharm Technol Res 2012;3:136.

12. Santhosh JU, Krishna MJ, Semotiuk AJ, Krishna V. Indigenous knowledge on medicinal plants used by ethnic communities of South India. Ethnobot Res Appl 2019;18:1-12.

13. Chandrashekara UM, Thasini VM. Non-crop edible plants and medicinal plants in homegarden agroforestry system of Palakkad district, Kerala. Int J Ecol Environ Sci 2016;42:183-91.

14. Iswariya S, Uma TS. Evaluation of in vitro anti-inflammatory and antimicrobial activity of aqueous and methanolic seed extracts of Citrullus lanatus. Int J Pharm Pharm Sci 2017;9:29-33.

15. Balouiri M, Sadiki M, Ibnsouda SK. Methods for in vitro evaluating antimicrobial activity: A review. J Pharm Anal 2016;6:71-9.

16. Cowan MM. Plant products as antimicrobial agents. Clin Microbiol Rev 1999;12:564-82

17. Stepanović S, Antić N, Dakić I, Švabić-Vlahović M. In vitro antimicrobial activity of propolis and synergism between propolis and antimicrobial drugs. Microbiol Res 2003;158:353-7.

18. Buwa LV, van Staden J. Antibacterial and antifungal activity of traditional medicinal plants used against venereal diseases in South Africa. J Ethnopharmacol 2006;103:139-42.

19. Grant NH, Alburn HE, Kryzanauskas C. Stabilization of serum albumin by anti-inflammatory drugs. Bioche Pharmacol 1970;19:715-22.

20. Krishnananda KK, Ramakrishna S. Comparison of antibacterial activity of leaves extracts of Tectona grandis, Mangifera indica, and Anacardium occidentale. Int J Curr Pharm Res 2017;9:36-9. 